\title{
Germination responses of the invasive Calotropis procera (Ait.) R. Br. (Apocynaceae): comparisons with seeds from two ecosystems in northeastern Brazil
}

\author{
LAURA C. LEAL ${ }^{1}$, MARCOS V. MEIADO ${ }^{1,2}$, ARIADNA V. LOPES ${ }^{3}$ and INARA R. LEAL ${ }^{3}$ \\ ${ }^{1}$ Programa de Pós-Graduação em Biologia Vegetal, Universidade Federal de Pernambuco, \\ Av. Professor Moraes Rego, s/n, Cidade Universitária, 50670-901 Recife, PE, Brasil \\ ${ }^{2}$ Departamento de Biociências, Universidade Federal de Sergipe, \\ Av. Vereador Olímpio Grande, s/n, Centro, 40500-000 Itabaiana, SE, Brasil \\ ${ }^{3}$ Departamento de Botânica, Universidade Federal de Pernambuco, \\ Av. Professor Moraes Rego, s/n, Cidade Universitária, 50670-901 Recife, PE, Brasil
}

Manuscript received on April 28, 2011; accepted for publication on June 6, 2012

\begin{abstract}
Life history traits are considered key indicators of plant invasibility. Among them, the germination behavior of seeds is of major relevance because it is influenced by environmental factors of invaded ecosystem. Here, we investigated how seed traits and seed tolerance to environmental factors on seed germination of Calotropis procera vary depending on the invaded ecosystems in northeastern Brazil. We have tested seeds from two vegetation types - Caatinga and Restinga - to different levels of light intensity, salinity, and water stress. Previous to those experiments, seed-set and morphometric analysis were carried out for both studied populations. We have observed a higher seed-set in Caatinga. Seeds produced in this ecosystem had lower seed moisture content. Seeds from Restinga showed lower germination time when light intensity decreased. We observed a reduction in both the germinability and the synchronization index with decreasing osmotic potential and increasing salinity. Nevertheless, both populations exhibited changes in photoblastism when seeds were submitted to water and saline stress. In conclusion, C. procera seeds are tolerant to environmental factors assessed. That characteristic ensures the colonization success and wide distribution of this plant species in the studied ecosystems.
\end{abstract}

Key words: biological invasions, Caatinga, environmental factors, Restinga, seed germination, seed-set.

\section{INTRODUCTION}

To understand how environmental factors affect seed germination responses it is essential to comprehend processes as establishment, succession and natural regeneration of vegetation (Bazzaz 1979, VázquezYanes and Orozco-Segovia 1993). In natural habitats, seed germination and seedling establishment are affected by environmental factors such as light

Correspondence to: Inara Roberta Leal

E-mail: irleal@ufpe.br intensity, temperature, water availability, and soil salinity (Baskin and Baskin 1988). Thus, it is possible to assert that the range of environmental conditions may be pointed out as one of the factors affecting seed germination and, consequently, the distribution of many plant species (Labouriau 1983, Baskin and Baskin 1998, Donohue et al. 2010). In addition, seed germination may also be affected by environmental conditions to which mother plants were exposed during seed development (Delesalle and Blum 1994). 
Studies on seed traits and germination behavior have been useful in the investigation of environmental factors affecting geographic distribution of native species (Abreu and Garcia 2005, Donohue et al. 2010, Silveira et al. 2011). Furthermore, such investigations are important tools for understanding colonization abilities and geographical distribution of exotic plants introduced in new habitats (Smith and Knapp 2001). When species with high dispersal capacity are removed from their native habitat and introduced into an exotic one, they may find favorable microclimatic and ecological conditions (e.g. predators and competitors absence) to the establishment of viable populations without human assistance (Richardson et al. 2000). Species that have this ability may become a serious threat to native species, and identifying factors that affect or favors the establishment of exotic species is important to guide strategies for prevention and control of invasive alien plant species worldwide (Smith and Knapp 2001).

Thus, the aim of this study was to evaluate if seed traits and germination responses to environmental factors of an invasive species vary depending on the invaded ecosystem. For that we studied populations of Calotropis procera (Ait.) R. Br. (Apocynaceae), an invasive plant of two Brazilian northeastern ecosystems - Caatinga and Restinga. Our discussion contributes to the characterization of invasive species traits, focusing on how environmental factors of the invaded ecosystem can influence the establishment of invasive alien plant species.

\section{MATERIALS AND METHODS}

STUdy AREA AND SPECIES

The study was carried out with seeds of Calotropis procera collected in two Brazilian northeastern ecosystems - Caatinga and Restinga. The Caatinga is a mosaic of seasonally tropical dry forest (sensu Mooney et al. 1995, Pennington et al. 2000) and scrub vegetation that covers an area of $730,000 \mathrm{~km}^{2}$ (Sampaio 1995). Seeds were collected in a population located at Serra Talhada $\left(7^{\circ} 59^{\prime} \mathrm{S}, \quad 38^{\circ} 19^{\prime} \mathrm{W}\right)$, Pernambuco State, northeast Brazil. Annual rainfall in the region is $\sim 803 \mathrm{~mm}$, the average temperature is $26^{\circ} \mathrm{C}$ and there is a pronounced dry season, that occurs between June and December (Machado et al. 1997). The predominant soils are Cambisoils and Litosoils with marked salinity due to salt accumulation resulting from fast water evaporation and poor soil drainage. Vegetation is dominated by shrubs of 3 to $4 \mathrm{~m}$ tall (Machado et al. 1997). The herbaceous stratum has low density and is composed mainly by annual species that are present only during the rainy season (Machado et al. 1997).

In Restinga, seeds of $C$. procera were collected from a population located a few meters away from the sea, in Caucaia $\left(03^{\circ} 44^{\prime} \mathrm{S}, 38^{\circ} 39^{\prime} \mathrm{W}\right)$, Ceará State, northeast Brazil. The average temperature in the region varies between 25 and $27^{\circ} \mathrm{C}$, with maximum amplitude of $5^{\circ} \mathrm{C}$ (Holanda et al. 2003). The annual rainfall is $\sim 1,255 \mathrm{~mm}$, with the dry season occurring between July and December (Holanda et al. 2003). The soil is formed by nonconsolidated sand and clay sedimentary particles, with the formation of mobile dunes characterized by the absence of plants or the fixation of vegetation in some places which attenuates the wind dynamics (Holanda et al. 2003).

Calotropis procera is popularly known in Brazil as "algodão-de-seda", "algodão brabo", "algodão-de-praia" or "leiteiro" because of the long white fibers attached to its seeds as an adaptation to wind dispersal. Calotropis procera has a wide geographical distribution, mainly in semiarid areas (Melo et al. 2001). The species is native from Africa, India, Persia, and Afghanistan. It has been naturalized in Australia, Mexico, Central America, South America, Caribbean and Pacific Islands (Rahman and Wilcock 1991). Calotropis procera has some attributes commonly found in invasive plants such as continuous flowering and 
autogamy in invaded areas, high seed production efficiently dispersed by wind, and fast growth after establishment (G.M. Tabatinga, unpublished data, Sobrinho et al. 2013). However, environmental factors that affect seed germination, establishment and distribution of this species have not been studied in detail.

In Brazil, C. procera was probably introduced as an ornamental in the early $20^{\text {th }}$ century (Kissmann and Groth 1992). Later, it became invasive of pasture areas, due to the high dissemination of its seeds by the wind (Corrêa 1939). Currently, the species can be easily found in areas of Caatinga and Restinga and is considered a threat to the native vegetation (Souza and Lorenzi 2005). It is a common species in pasture areas, road margins and cultivated areas, forming dense populations that are difficult to eradicate (Melo et al. 2001).

\section{SEED-SET, MORPHOMETRY AND GERMINATION}

During May (wet season at Caatinga study site) and June (wet season at Restinga study site) of 2007, we collected 30 fruits per ecosystem, one fruit per individual (randomly selected in both populations/ ecosystems). All the fruits were completely developed but still closed, thus we could verify the seed-set. We measured the length and width of seeds (mm), dry biomass ( $\mathrm{mg}$ ), and the seed moisture content (\%). All the morphometric parameters followed the Brazilian Norms for Seeds Analysis (Brasil 2009). We used 30 samples of 10 seeds each (one sample per individual) to check the dry biomass, seed moisture content, length and width of the seeds.

We assessed the effect of light intensity, salinity and water stress on seed germination of both populations. Values of light intensity, water and salinity stress used in these experiments were calculated in order to simulate the range of abiotic conditions to which Calotropis procera can be submitted in both ecosystems. We used five Petri dishes with 50 seeds each per treatment watered with the test solutions. In each dish, we used seeds from one individual of each population randomly selected. The different levels of light intensity $(0,30,50,70$ and $100 \%$, which represented the full light treatment with a light intensity of 20 $\mu$ mol. $\mathrm{m}^{-2} . \mathrm{s}^{-1}$ ) were simulated with the use of black polypropylene shade cloth. We used a commercial solution of sodium chloride (Braccini et al. 1996) and polyethylene glycol 6000 (Villela et al. 1991) to simulate the salinity and water stress, respectively. In both experiments, we evaluated the effect of osmotic potentials $0.0,-0.2,-0.4,-0.6,-0.8$ and $-1.0 \mathrm{MPa}$ on seed germination. The dishes were placed in ideal conditions for the C. procera seed germination, according to Labouriau and Valadares (1976) (i.e., constant temperature of $30^{\circ} \mathrm{C}$, under light or continuous darkness, simulated with the use of black plastic bags). The radicle protrusion was the criterion for germination seeds. The evaluations were made daily for a period of 35 days.

\section{DATA ANALYSIS}

We compared seed-set and morphometric parameters between the two populations with $t$ tests. For each seed germination treatment, we calculated: 1) germinability $(\%)$; 2) mean germination time $[t=\Sigma n i . t i / \Sigma n i$, where $t i$ is the time from the start of the experiment to the $i^{\text {th }}$ observation (day), and $n i$ is the number of seeds germinated in the time $i$ (not the accumulated number, but the number correspondent to the $i^{\text {th }}$ observation)]; and 3) the synchronization index of germination $\left[E=-\Sigma f\right.$ i. $\log _{2}$. $f i$, where $f i$ is the relative frequency of germination (i.e., the proportion of germinated seeds in an interval)] according to Ranal and Santana (2006). The germinability data were arcsine square-root transformed in order to adjust count data to the normal distribution and apply parametric tests. For the evaluation of light intensity effects we used a Two Way ANOVA (ecosystem and light intensity). To verify the influence of the water stress between the populations and to check for the existence of a 
photoblastic change in the seeds submitted to the treatments, we compared the germination of all treatments using a Three Way ANOVA (ecosystem, photoblastism and water availability). The same analysis was conducted with germination data of seeds submitted to saline stress. We verified the normality of the residuals and homogeneity of the variances through Shapiro-Wilk and Levene tests, respectively. All statistical analyses are described in Zar (1999) and were assessed with STATISTICA 7.0 with a significance level equal to 0.05 .

\section{RESULTS}

The number of seeds per fruit of Calotropis procera ranged from 213 to 391 in Caatinga and 162 to 403 in Restinga, which resulted in a seed production in Caatinga $11.85 \%$ higher than in Restinga ( $t=3.01$, $\mathrm{df}=58, P=0.004$, Table I). For the morphometric parameters, we found no significant differences in seed length $(t=-0.49$, df $=58, P=0.630)$, seed width $(t=-0.57, \mathrm{df}=58, P=0.571)$, or dry biomass ( $t=0.75$, df $=58, P=0.480$, Table I) between ecosystems. For seed moisture, however, we found a water content about $60 \%$ lower in the Caatinga ( $t$ $=-5.60, \mathrm{df}=58, P<0.001$, Table I) compared to the Restinga population.

Seeds of $C$. procera showed a positive response to a wide range of environmental factors. The germinability was not influenced by the variation in light intensity $(\mathrm{F}=0.40, \mathrm{df}=4, P=$ 0.770 ), with seeds of both populations having a final germination superior to $95 \%$ (Table II). Similarly, the synchronization index of seed germination was not influenced by the different levels of light intensity ( $\mathrm{F}=1.10, \mathrm{df}=4, P=0.380$, Table II). On the other hand, the mean germination time was affected by the ecosystem $(\mathrm{F}=27.42, \mathrm{df}=4, P<0.001)$ and light intensity $(\mathrm{F}=8.61, \mathrm{df}=4 ; P<0.001)$. Seeds from Restinga germinated more rapidly when exposed to lower light intensities (Table II).

TABLE I

Number of seeds per fruit unit and dimensions, dry biomass and moisture content of Calotropis procera (Ait.) R. Br. (Apocynaceae) seeds collected in the same developmental stage in Caatinga and Restinga areas of northeastern Brazil. Different letters in the same column indicate significant differences between ecosystems. Data are expressed as mean $\pm \mathrm{SE}$.

\begin{tabular}{cccccc}
\hline & Seeds per Fruit & Seed Length $(\mathrm{mm})$ & Seed Width $(\mathrm{mm})$ & Dry Biomass $(\mathrm{mg})$ & Seed Moisture Content $(\%)$ \\
\hline Caatinga & $329 \pm 43 \mathrm{a}$ & $6.3 \pm 0.3 \mathrm{a}$ & $4.2 \pm 0.2 \mathrm{a}$ & $56.5 \pm 8.1 \mathrm{a}$ & $9.3 \pm 0.9 \mathrm{~b}$ \\
Restinga & $290 \pm 57 \mathrm{~b}$ & $6.3 \pm 0.3 \mathrm{a}$ & $4.2 \pm 0.2 \mathrm{a}$ & $56.3 \pm 7.8 \mathrm{a}$ & $15.4 \pm 5.9 \mathrm{a}$ \\
\hline
\end{tabular}

TABLE II

Germination parameters of Calotropis procera (Ait.) R. Br. (Apocynaceae) seeds from two ecosystems of northeastern Brazil (Caatinga and Restinga) subjected to light treatments at $30^{\circ} \mathrm{C}$ after 35 days. Different capital and small letters indicate significant differences between ecosystem type and light treatments, respectively. Data are expressed as mean $\pm \mathrm{SE}$.

\begin{tabular}{ccccccc}
\hline \multirow{2}{*}{$\begin{array}{c}\text { Light Intensity } \\
(\%)\end{array}$} & \multicolumn{2}{c}{ Germinability (\%) } & \multicolumn{2}{c}{ Mean Germination Time (day) } & \multicolumn{2}{c}{ Synchronization Index } \\
\cline { 2 - 7 } Caatinga & Restinga & Caatinga & Restinga & Caatinga & Restinga \\
\hline 0 & $97.6 \pm 5.37 \mathrm{Aa}$ & $100 \pm 0.0 \mathrm{Aa}$ & $2.03 \pm 0.09 \mathrm{Ab}$ & $0.97 \pm 0.04 \mathrm{Ab}$ & $0.12 \pm 0.20 \mathrm{Aa}$ & $0.16 \pm 0.22 \mathrm{Aa}$ \\
30 & $98.4 \pm 2.19 \mathrm{Aa}$ & $98.8 \pm 1.79 \mathrm{Aa}$ & $2.91 \pm 1.24 \mathrm{Aab}$ & $2.20 \pm 0.43 \mathrm{Aab}$ & $0.37 \pm 0.27 \mathrm{Aa}$ & $0.03 \pm 0.06 \mathrm{Aa}$ \\
50 & $99.2 \pm 1.79 \mathrm{Aa}$ & $100 \pm 0.0 \mathrm{Aa}$ & $3.27 \pm 0.65 \mathrm{Aab}$ & $2.28 \pm 0.37 \mathrm{Aab}$ & $0.42 \pm 0.76 \mathrm{Aa}$ & $0.58 \pm 0.40 \mathrm{Aa}$ \\
70 & $99.6 \pm 0.89 \mathrm{Aa}$ & $100 \pm 0.0 \mathrm{Aa}$ & $3.36 \pm 1.08 \mathrm{Aab}$ & $2.51 \pm 0.32 \mathrm{Aa}$ & $0.36 \pm 0.13 \mathrm{Aa}$ & $0.67 \pm 0.22 \mathrm{Aa}$ \\
100 & $97.2 \pm 6.26 \mathrm{Aa}$ & $100 \pm 0.0 \mathrm{Aa}$ & $4.05 \pm 1.01 \mathrm{Aa}$ & $2.38 \pm 0.44 \mathrm{Bab}$ & $0.80 \pm 0.72 \mathrm{Aa}$ & $0.54 \pm 0.48 \mathrm{Aa}$ \\
\hline
\end{tabular}


The salinity stress negatively influenced the germinability of $C$. procera $(\mathrm{F}=107.29, \mathrm{df}=5, P<$ 0.001 ), completely inhibiting it in both population when seeds were submitted to a concentration equal or higher than $-0.8 \mathrm{MPa}$ (Fig. 1A). With increase in salinity concentration, we found changes in the photoblastic response of both populations, with a higher germinability in the darkness $(\mathrm{F}=50.12$, df $=1, P<0.001)$. We did not observe statistical significant differences in the germinability between the populations subjected to different salinity concentrations $(\mathrm{F}=0.21$, $\mathrm{df}=1, P=0.956)$. However, the synchronization index of seed germination under the influence of salinity stress was higher in the absence of light $(\mathrm{F}=8.83, \mathrm{df}=1$, $P<0.001)$. Moreover, there was no significant difference in the mean germination time between ecosystems $(\mathrm{F}=0.23, \mathrm{df}=1, P=0.630$, Table III).

\section{TABLE III}

Germination parameters of Calotropis procera (Ait.) R. Br. (Apocynaceae) seeds from two ecosystems of northeastern Brazil (Caatinga and Restinga) and subjected to salinity stress in light and darkness at $30^{\circ} \mathrm{C}$ after 35 days. Greek, capital and small letters indicate statistic results of comparisons between photoblastism, ecosystem type and salinity treatments, respectively. Data are expressed as mean $\pm \mathrm{SE}$.

\begin{tabular}{|c|c|c|c|c|c|}
\hline \multirow{2}{*}{$\begin{array}{l}\text { Light } \\
\text { Regime }\end{array}$} & \multirow{2}{*}{$\begin{array}{l}\text { Salinity } \\
(\mathrm{MPa})\end{array}$} & \multicolumn{2}{|c|}{ Mean Germination Time (day) } & \multicolumn{2}{|c|}{ Synchronization Index } \\
\hline & & Caatinga & Restinga & Caatinga & Restinga \\
\hline \multirow{6}{*}{ Light } & 0.0 & $4.05 \pm 1.01 \alpha \mathrm{Aa}$ & $2.38 \pm 0.51 \alpha \mathrm{Aa}$ & $0.80 \pm 0.71 \alpha \mathrm{Aa}$ & $0.54 \pm 0.47 \alpha \mathrm{Aa}$ \\
\hline & 0.2 & $4.97 \pm 3.51 \alpha \mathrm{Aa}$ & $3.52 \pm 2.50 \alpha \mathrm{Aa}$ & $0.98 \pm 0.84 \alpha \mathrm{Aa}$ & $0.35 \pm 0.47 \alpha \mathrm{Aa}$ \\
\hline & 0.4 & $7.60 \pm 11.26 \alpha \mathrm{Aa}$ & $5.55 \mathrm{~b} \pm 8.07 \alpha \mathrm{Aa}$ & $0.20 \pm 0.44 \alpha \mathrm{Aa}$ & $0.00 \pm 0.00 \alpha \mathrm{Aa}$ \\
\hline & 0.6 & $2.20 \pm 3.03 \alpha \mathrm{Aa}$ & - & $0.00 \pm 0.00 \alpha \mathrm{Aa}$ & $0.00 \pm 0.00 \alpha \mathrm{Aa}$ \\
\hline & 0.8 & - & - & - & - \\
\hline & 1.0 & - & - & - & - \\
\hline \multirow{6}{*}{ Darkness } & 0.0 & $2.03 \pm 0.11 \alpha \mathrm{Aa}$ & $0.97 \pm 0.04 \alpha \mathrm{Aa}$ & $0.12 \pm 0.20 \alpha \mathrm{Aa}$ & $0.16 \pm 0.22 \alpha \mathrm{Ab}$ \\
\hline & 0.2 & $2.59 \pm 0.44 \alpha \mathrm{Aa}$ & $1.96 \pm 0.08 \alpha \mathrm{Aa}$ & $0.38 \pm 0.30 \alpha \mathrm{Aa}$ & $0.14 \pm 0.30 \alpha \mathrm{Ab}$ \\
\hline & 0.4 & $3.56 \pm 0.34 \alpha \mathrm{Aa}$ & $3.67 \pm 0.87 \alpha \mathrm{Aa}$ & $0.82 \pm 0.46 \alpha \mathrm{Aa}$ & $1.44 \pm 0.40 \alpha \mathrm{Aa}$ \\
\hline & 0.6 & $6.54 \pm 2.29 \alpha \mathrm{Aa}$ & $5.48 \pm 3.15 \alpha \mathrm{Aa}$ & $0.82 \pm 0.64 \alpha \mathrm{Aa}$ & $0.39 \pm 0.90 \alpha \mathrm{Aa}$ \\
\hline & 0.8 & - & - & - & - \\
\hline & 1.0 & - & - & - & - \\
\hline
\end{tabular}

- No seed germination.

As observed with the saline stress, the populations exhibited changes in the photoblastism when subjected to water stress $(\mathrm{F}=238.69, \mathrm{df}=4$, $P<0.001)$. The reduction in the availability of water also negatively affected the synchronization index $(\mathrm{F}$ $=5.80, \mathrm{df}=4, P<0.001)$ and germinability $(\mathrm{F}=$ 10.28 , df $=4, P<0.001$, Fig. 1B), with seeds from Caatinga germinating at concentration of $-0.8 \mathrm{MPa}$, while the germination was inhibited at concentrations of less than -0.4 MPa in seeds from Restinga. With reduction of water availability, we also found a significantly increase in mean germination time $(\mathrm{F}=7.48, \mathrm{df}=4, P<0.001$, Table IV).

\section{DISCUSSION}

Plant phenotype variation might be affected not only by the genotype, but also by the environment where plants live as well as by the conditions to which the parental plants are growing (Delesalle and Blum 1994, Roach and Wullf 1987). Thus, we 
(A)

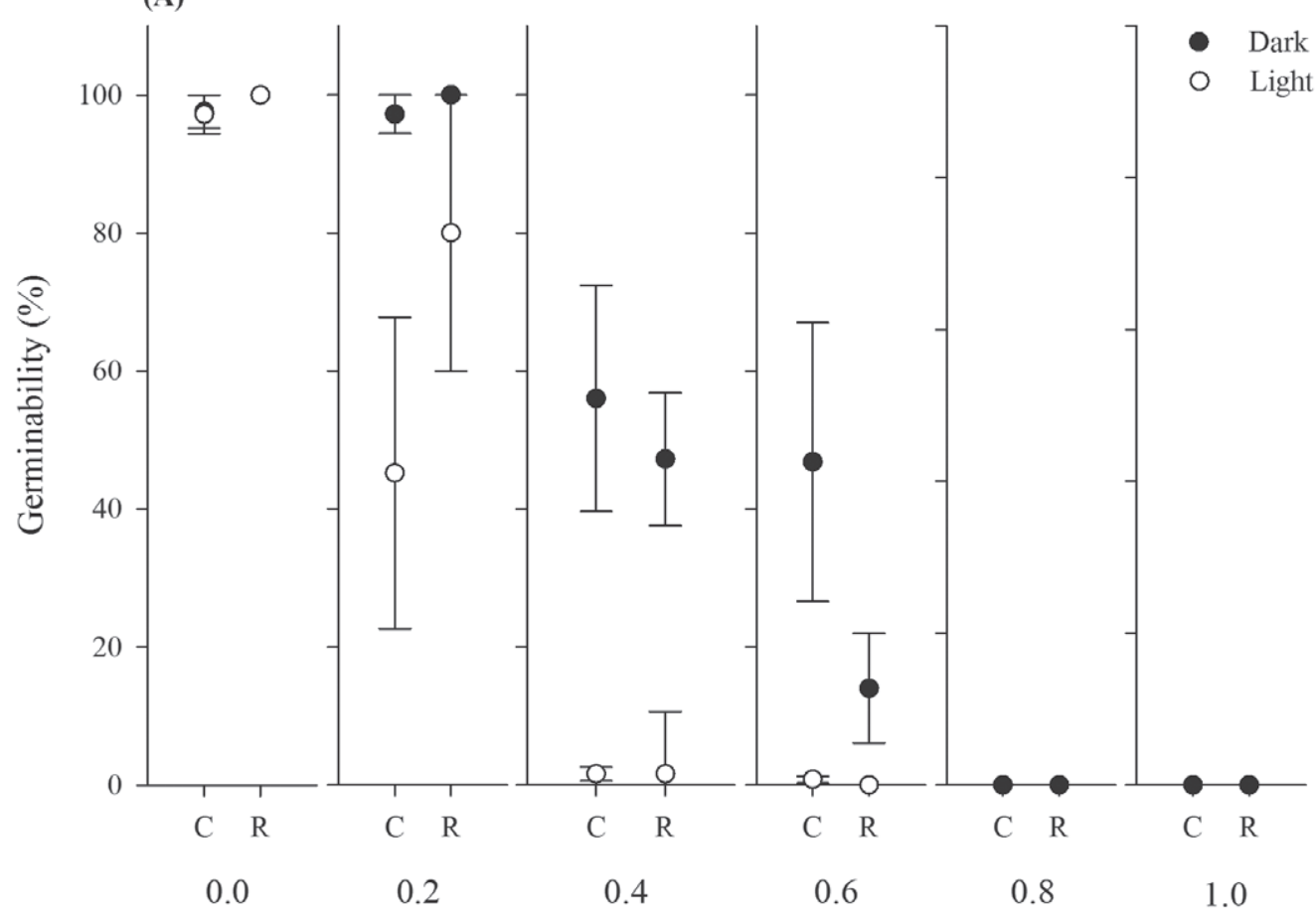

(B)

NaCl solutions (MPa)

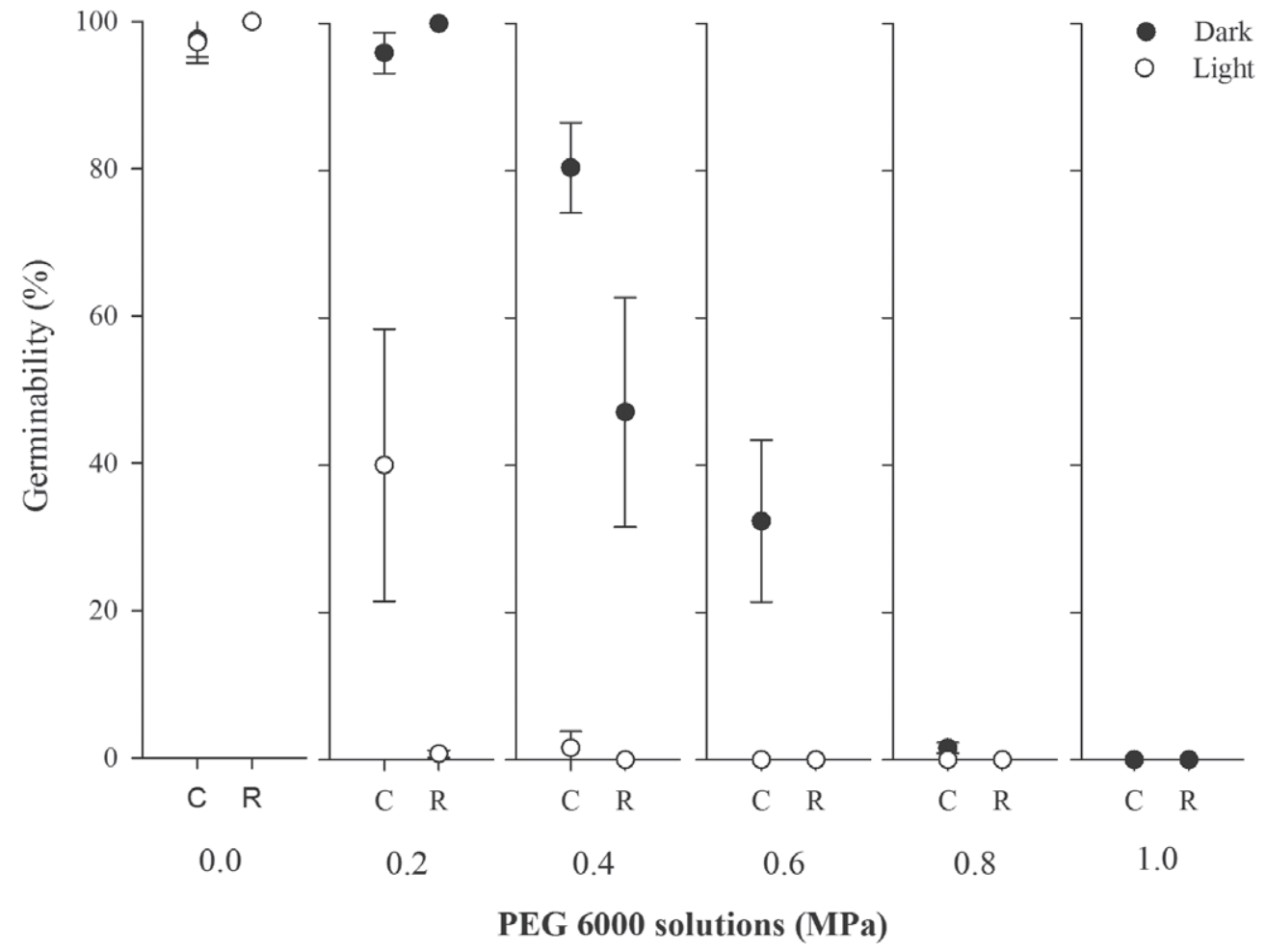

Fig. 1 - Germinability (\%) of Calotropis procera (Ait.) R. Br. (Apocynaceae) seeds from Caatinga (C) and Restinga (R), northeastern Brazil, subjected to saline (A) and water stress (B) in light and darkness at $30^{\circ} \mathrm{C}$ after 35 days. Bars indicate \pm SE. 
TABLE IV

Germination of Calotropis procera (Ait.) R. Br. (Apocynaceae) seeds from two ecosystems of northeastern Brazil (Caatinga and Restinga) and subjected to water stress in light and darkness at $30^{\circ} \mathrm{C}$ after 35 days. Greek, capital and small letters indicate significant differences between photoblastism, ecosystem type and water stress treatments, respectively. Data are expressed as mean $\pm \mathrm{SE}$.

\begin{tabular}{|c|c|c|c|c|c|}
\hline \multirow{2}{*}{$\begin{array}{l}\text { Light } \\
\text { regimes }\end{array}$} & \multirow{2}{*}{$\begin{array}{c}\text { Treatments } \\
(\mathrm{MPa})\end{array}$} & \multicolumn{2}{|c|}{ Mean Germination Time (day) } & \multicolumn{2}{|c|}{ Synchronization Index } \\
\hline & & Caatinga & Restinga & Caatinga & Restinga \\
\hline \multirow{6}{*}{ Light } & 0.0 & $4.05 \pm 1.01 \alpha \mathrm{Ab}$ & $2.38 \pm 0.51 \alpha \mathrm{Aa}$ & $0.80 \pm 0.71 \alpha \mathrm{Aa}$ & $0.54 \pm 0.47 \alpha \mathrm{Aa}$ \\
\hline & 0.2 & $12.42 \pm 6.92 \alpha \mathrm{Aa}$ & $2.80 \pm 3.83 \alpha \mathrm{Ba}$ & $0.66 \pm 0.46 \alpha \mathrm{Aa}$ & $0.00 \pm 0.00 \alpha \mathrm{Aa}$ \\
\hline & 0.4 & $10.37 \pm 10.83 \alpha \mathrm{Aa}$ & $0.00 \pm 0.00 \alpha \mathrm{Ba}$ & $0.25 \pm 0.56 \alpha \mathrm{Aa}$ & $0.00 \pm 0.00 \beta \mathrm{Aa}$ \\
\hline & 0.6 & - & - & - & - \\
\hline & 0.8 & - & - & - & - \\
\hline & 1.0 & - & - & - & - \\
\hline \multirow{6}{*}{ Darkness } & 0.0 & $2.03 \pm 0.09 \alpha \mathrm{Aa}$ & $0.97 \pm 0.04 \alpha \mathrm{Aa}$ & $0.12 \pm 0.20 \alpha \mathrm{Ad}$ & $0.16 \pm 0.22 \alpha \mathrm{Aab}$ \\
\hline & 0.2 & $2.71 \pm 0.31 \beta \mathrm{Aa}$ & $2.00 \pm 0.00 \alpha \mathrm{Aa}$ & $0.46 \pm 0.38 \alpha$ Acd & $0.00 \pm 0.00 \alpha \mathrm{Ab}$ \\
\hline & 0.4 & $4.26 \pm 0.50 \alpha \mathrm{Aa}$ & $3.50 \pm 0.37 \alpha \mathrm{Aa}$ & $1.25 \pm 0.55 \alpha \mathrm{Ab}$ & $0.87 \pm 0.50 \alpha \mathrm{Aa}$ \\
\hline & 0.6 & $8.03 \pm 1.93 \alpha \mathrm{Aa}$ & $0.00 \pm 0.00 \alpha \mathrm{Aa}$ & $1.82 \pm 0.45 \alpha \mathrm{Aa}$ & $0.00 \pm 0.00 \alpha \mathrm{Bb}$ \\
\hline & 0.8 & $10.50 \pm 9.63 \alpha \mathrm{Aa}$ & $0.00 \pm 0.00 \alpha \mathrm{Aa}$ & $0.20 \pm 0.45 \alpha \mathrm{Ac}$ & $0.00 \pm 0.00 \alpha \mathrm{Ab}$ \\
\hline & 1.0 & - & - & - & - \\
\hline
\end{tabular}

- No seed germination.

expected that individuals from different populations would differ in morphological or physiological adaptations, which allow them to establish in several habitats. Seed-set is one of the main phases of plants life cycle. This phase can be affected by environmental pressures suffered by parental plants in the site where they are established (Roach and Wullf 1987). We observed significant differences in seed-set between populations, which indicated that C. procera can produce different number of seeds depending on the invaded environment. Although seed-set may varies between years, the dry season preceding fruit collection was typical in both ecosystems. This fact leads us to believe that the differences between populations are not result of atypical climatic variations during the production of the fruits used in these experiments.

Seeds of Calotropis procera from both populations/ecosystems are aphotoblastic (sensu Ferreira et al. 2001) and had the same germination behavior in the presence or absence of light, with a mean germination time less than 5 days. The mean germination time represents an important parameter in seed germination studies, especially for alien plant species, as it is a useful parameter for the evaluation of niche occupation speed and efficiency (Abreu and Garcia 2005). Reduction in light intensity caused a reduction in the mean germination time, with the higher average found in seeds in a constant darkness. Thus, the germinability and the efficiency of space occupation of this species are positively favored by the absence of light. Moreover, under the influence of water and salinity stress the seeds showed a type of photoblastism, behaving as "relative negative photoblastic" (sensu Ferreira et al. 2001), indicating, once more, that the success of establishment is higher when seeds are in darkness.

Many alien plants show an increase in their germination rates when exposed to high light conditions, which favors their performance in disturbed areas (Harradine 1991). Seeds of 
Cortaderia jubata (Lemoine) Stapf (Poaceae), an invasive species of coastal California, for example, have 3.3 times higher germinability in high light than in dark (Drewitz and DiTomaso 2004). However, the ability to germinate under different degrees of light intensity, like observed here, can increase the invasion ability. Thus, these alien plants can colonize many habitats with a wide spectrum of light conditions. Other alien species show photoblastic germination behavior similar to that found in C. procera, such as Cortaderia selloana (Schultes \& Schultes fil.) Asch. \& Graebner (Poaceae) seeds. It is an European alien plant, which presents high germination rate under different light conditions, but are favored by light intensity below 100\% (Domènech and Vilà 2008).

The ecosystems where the two studied populations were located are marked by a high soil salinity, either by fluvial-marine influence, such as in the Restinga (Sugiyama 1998), or by the high water evaporation and deficient drainage of soil, resulting in the accumulation of salt in the Caatinga soils (Fassbender and Bornemisza 1987, Mello et al. 1983). Thus, due to the high occurrence of individuals in those environments, we expected a similar seed germination response to salinity for both populations, which was confirmed in our results. In fact, plant species of arid ecosystems usually exhibit high tolerance to salinity (Gutterman 1993, Kigel 1995). On the other hand, water availability differs between ecosystems, with Restinga areas showing higher pluviometric rates and air relative humidity than Caatinga. However, part of the water in this environment might not be available for the plants due to the high concentration of salt in water (Miller and Donahue 1990). Thus, in Restinga, plants have several strategies to promote water absorption, most of them involving energetic expenses (Miller and Donahue 1990). Based on these statements, we expected that seeds from Restinga had higher seed moisture content, as these seeds lose less water during the seed development. In fact, this pattern was observed in our studies. Seeds collected in the Restinga had higher levels of water content than those collected in Caatinga. According to Castro et al. (2004), higher levels of moisture make seeds more sensitive to water stress during the germination period, and this was observed in our results.

In conclusion, although we found some differences in seed attributes and germination response of Calotropis procera between Caatinga and Restinga, both populations showed high germination success. They showed a reduction in the synchronization index of germination and an increase in the mean germination time. Further, seeds from both ecosystems showed positive responses to a wide range of environmental factors. Thus, these factors do not act as barriers to the invasive capacity of $C$. procera, ensuring its colonization success and wide distribution in both ecosystems. Based on its seed-set, seed size, dispersal mode and germination behavior, $C$. procera seems to be an effective invasive species in Caatinga and Restinga areas, and its potential to invade other ecosystems in the world should be considered.

\section{ACKNOWLEDGMENTS}

The study was supported by the Coordenação de Aperfeiçoamento de Pessoal de Nível Superior (CAPES, PROCAD Grant number 0166057). The Centro de Pesquisas Ambientais do Nordeste (CEPAN) and The Conservação Internacional do Brasil (CI-Brasil) provided logistic support during field work. We are also grateful to the Conselho Nacional de Desenvolvimento Científico e Tecnológico (CNPq), which provided an undergraduate fellowship to L. C. Leal and research grants to A. V. Lopes and I. R. Leal.

\section{RESUMO}

Características da história de vida são consideradas indicadoras chave do potencial invasivo de vegetais. Dentre essas características, o comportamento germinativo de sementes é de grande relevância, pois é influenciado 
por fatores ambientais do ecossistema invadido. Aqui, investigamos como características das sementes de Calotropis procera e sua tolerância a fatores ambientais na germinação varia dependendo do ecossistema invadido no Nordeste do Brasil. Nós testamos o comportamento germinativo de sementes de duas populações - Caatinga e Restinga - sob diferentes níveis de luminosidade, salinidade e déficit hídrico. Nós também quantificamos as sementes produzidas por fruto em cada população e realizamos análise morfométrica das sementes. Nós observamos maior número de sementes em frutos de Caatinga e as sementes produzidas nesse ecossistema tiveram menor teor de umidade. Com o decréscimo da intensidade luminosa, sementes de Restinga apresentaram menor tempo médio de germinação. Nós também observamos redução na germinabilidade e na sincronização da germinação com o descréscimo do potencial osmótico e com o aumento da salinidade. Ambas populações exibiram mudanças no fotoblastismo quando sementes foram submetidas a estresse salino e hídrico. Dessa forma, concluímos que sementes de C. procera são tolerantes aos fatores ambientais testados e que essa característica pode ser responsável pelo sucesso de colonização da espécie nos ecossistemas estudados.

Palavras-chave: invasões biológicas, Caatinga, fatores ambientais, Restinga, germinação de sementes, produção de sementes.

\section{REFERENCES}

ABREU MEP AND GARCIA QS. 2005. Efeito da luz e da temperatura na germinação de sementes de quatro espécies de Xyris L. (Xyridaceae) ocorrentes na Serra do Cipó, MG, Brasil. Acta Bot Bras 19: 149-154.

BASKIN JM AND BASKIN CC. 1988. Germination ecophysiology of herbaceous plant species in a temperate region. Am J Bot 75: 286-305.

BASKIN JM AND BASKIN CC. 1998. Seeds: ecology, biogeography, and evolution of dormancy and germination. Academic Press, San Diego, 666 p.

BAZZAZ FA. 1979. The physiological ecology of plant succession. Annu Rev Ecol Evol S 10: 351-371.

BRACCINI AL, RUIZ HA, BRACCINI MCL AND REIS MS. 1996. Germinação e vigor de sementes de soja sob estresse hídrico induzido por soluções de cloreto de sódio, manitol e polietileno glicol. Rev Bras Sementes 18: 10-16.

BRASIL. 2009. Regras para análise de sementes. Ministério da Agricultura, Brasília, 399 p.
CAstro RD, BradFord KJ AND Hilhorst. HWM. 2004. Desenvolvimento de sementes e conteúdo de água. In: FERREIRA AG AND BORGUETTI F (Eds), Germinação: do básico ao aplicado. Porto Alegre: Artmed, Brasil, p. 52-71.

CORRÊA P. 1939. Dicionário das plantas úteis do Brasil e das Exóticas Cultivadas. Rio de Janeiro: Imprensa Nacional, $4324 \mathrm{p}$.

Dallesalle VA AND Blum F. 1994. Variation in germination and survival among families of Sargitaria latifolia in response to salinity and temperature. Int J Plant Sci 155: 187-195.

DOMÈNECH R AND VILÀ M. 2008. Cortaderia selloana seed germination under different ecological conditions. Acta Oecol 33: 93-96.

Donohue K, Casas RR, Burghardt L, Kovach K AND WILlis CG. 2010. Germination, postgermination adaptation, and species ecological ranges. Annu Rev Ecol Evol Syst 41: 293-319.

DREWITZ JJ AND Ditomaso JM. 2004. Seed biology of jubatagrass (Cortaderia jubata). Weed Sci 52: 525-530.

FASSBENDER HW AND BORNEMISZA E. 1987. Química de suelos con énfasis en suelos de América Latina. San José: Instituto Interamericano de Cooperación para la Agricultura, $420 \mathrm{p}$.

Ferreira AG, Cassol B, Rosa SGT, Silveira TS, Stival AL AND Silva AA. 2001. Germinação de sementes de Asteraceae nativas do Rio Grande do Sul. Acta Bot Bras 15: 231-242.

GutTERMAN Y. 1993. Seed germination in desert plants. Berlin: Springer-Verlag, Germany, $252 \mathrm{p}$.

HARRADINE AR. 1991. The impact of pampas grass as weeds in southern Australia. Plant Protec Quart 6: 111-115.

Holanda JLR, VASCONCELOS SMS AND MAIA LP. 2003. Aspectos hidrogeológicos da região costeira do município de Caucaia - Ceará. Rev Geologia 16: 7-18.

KIGEL J. 1995. Seed germination in arid and semiarid regions. In: Kigel J and Galili G (Eds), Seed development and germination. New York: Marcel Dekker, Inc., USA, p. 645-699.

KisSMANN KG AND GROTH D. 1992. Plantas infestantes e nocivas. São Paulo: BASF S.A., 978 p.

LABOURIAU LG. 1983. A germinação de sementes. Washington: Secretaria Geral da Organização dos Estados Unidos Americanos, $174 \mathrm{p}$.

LABOURIAU LG AND VAladares MEB. 1976. On the germination of seeds of Calotropis procera (Ait.) Ait.f. An Acad Bras Cienc 48: 263-284.

Machado ICS, BARros LM AND SAMPAIO EVSB. 1997. Phenology of Caatinga species at Serra Talhada, PE, northeastern Brazil. Biotropica 29: 57-68.

Mello FAF, Sobrinho MOCB, Arzolla S, Silveira RI, NetTo AC AND KIEHL JC. 1983. Fertilidade do solo. São Paulo: Nobel, 400 p.

Melo MM, Vaz F, Gonçalves LC and Saturnino HM. 2001. Estudo fitoquímico da Calotropis procera Ait., sua utilização na alimentação de caprinos: efeitos clínicos e bioquímicos séricos. Rev Bras Saúde Prod An 2: 15-20. 
MiLler R AND DONAHUE RL. 1990. Soils: an introduction to soils and plant growth. New Jersey: Prentice Hall, 363 p.

MOONEY HA, BULLOCK SH AND MEDINA E. 1995. Introduction. In: Bullock SH, Mooney HA and Medina E (Eds), Seasonally dry tropical forests. Cambridge: Cambridge University Press, England, p. 1-8.

Pennington RT, PRAdo DE AND PENDRY CA. 2000. Neotropical seasonally dry forests and Quaternary vegetation changes. J Biogeogr 27: 261-273.

RAHMAN MA AND WILCOCK CC. 1991. A taxonomic revision of Calotropis (Asclepiadaceae). Nord J Bot 11: 301-308.

RANAL MA AND SANTANA DG. 2006. How and why to measure the germination process? Rev Bras Bot 29: 1-11.

RichaRdSON DM, PYSEK P, REJMÁNEK M, BARBOUR MG, PANETTA FD AND WeSt CJ. 2000. Naturalization and invasion of alien plants: concepts and definitions. Divers Distrib 6: 93-107.

RoACH DA AND WULLF RD. 1987. Maternal effects in plants. Annu Rev Ecol Evol S 18: 209-235.

SAMPAIO EVSB. 1995. Overview of the Brazilian Caatinga. In: Bullock SH, Mooney HA and Medina E (Eds), Seasonal dry tropical forests. Cambridge: Cambridge University Press, p. 35-63.

SilveIrA FAO, Negreiros D, ARAÚJO LM AND FERNANDES GW. 2011. Does seed germination contribute to ecological breadth and geographic range? A test with sympatric Diplusodon (Lythraceae) species from rupestrian fields. Plant Spec Biol 27: 170-173.
SMITH AK AND KNAPP MD. 2001. Variation among biomes in temporal dynamics of aboveground primary production. Science 291: 481-484.

SOBRINHO MS, TABATINGA GM, MACHADO IC AND LOPES AV. 2013. Reproductive phenological pattern of Calotropis procera (Apocynaceae), an invasive species in Brazil: annual in native areas; continuous in invaded areas of caatinga. Acta Bot Bras 27: 456-459.

SouZA VC AND LoRENZI H. 2005. Botânica sistemática. Nova Odessa: Instituto Plantarum, 640 p.

SugiYAmA M. 1998. Estudo de florestas da restinga da Ilha do Cardoso, Cananéia, São Paulo, Brasil. Bol Inst Bot 11: 119-159.

VÁZQUEZ-YANES AND OROZCO-SEGOVIA A. 1993. Patterns of seed longevity and germination in tropical rain forest. Ann Rev Ecol Evol S 24: 69-87.

Villela FA, Doni Filho L AND SEQUeIRA EL. 1991. Tabela de potencial osmótico em função da concentração de Polietileno Glicol 6.000 e da temperatura. Pesq Agropec Bras 26: 1957-1968.

ZAR JH. 1999. Biostatical analysis. New Jersey: Prentice Hall Inc., $662 \mathrm{p}$. 